\title{
Oude dozen met actuele thema's
}

\author{
Roel Schouteten*
}

Als gevolg van een bezuinigingsreorganisatie moest ik in december op mijn werk verhuizen. Uit kostenoverwegingen worden er kamers afgestoten en moest de hele faculteit wat indikken. Dat ging gepaard met een enorme verhuisoperatie, waarbij meer dan de helft van de medewerkers in de weer moest met verhuisdozen. Omdat ik zo veel mogelijk ballast voor de nieuwe start in de nieuwe kamer overboord wilde gooien, kostte het me veel tijd en energie om allerlei archiefkasten en mappen met scripties, cursusmateriaal, projectvoorstellen, analyseresultaten en stapels met (o zo interessante, maar nog steeds niet gelezen) artikelen door te spitten. Daarbij stuitte ik ook op een heleboel leuke of interessante verrassingen. Zo kwam ik een grote stapel oude en minder oude krantenknipsels tegen over onderwerpen die sterk aan mijn onderzoeksinteresses raken; stress, welzijn, ziekteverzuim, langer doorwerken en arbeidsomstandigheden. Het interessante aan deze stapel krantenknipsels (waardoor het ook zo veel tijd kost om het door te spitten) is dat ze in het licht van de huidige discussies over de verhoging van de pensioenleeftijd ${ }^{1}$ nog steeds zeer actuele inzichten bevatten.

Naar aanleiding van het uit bezuinigingsnoodzaak geboren plan om de AOW-leeftijd naar 67 jaar te verhogen, is er een discussie op gang gekomen over de vraag wat zware beroepen zijn. Minister Donner heeft als tegemoetkoming aan de vakbonden toegezegd dat er voor werknemers in zware beroepen uitzonderingen op de verhoging van de AOW-leeftijd gemaakt kunnen worden. Daarbij denkt de minister in eerste instantie aan fysiek zware beroepen, die onherstelbare schade aan het gestel van werknemers veroorzaken. Terecht wijzen TNO-onderzoekers er in ESB (13-11-2009) op dat niet alleen fysieke belasting, maar ook mentale (psychische) belasting, en zeker de combinatie van fysieke en mentale belasting, tot ernstige arbeidsuitval kunnen leiden. Zeker in een land waar veel meer mensen in de dienstensector werken dan in de (zware) industrie. De minister is echter van mening dat werkgevers ervoor verantwoordelijk zijn om dit soort werk te voorkomen dan wel te beperken. Daarmee stelt hij werkgevers verantwoordelijk voor de duurzame inzetbaarheid van werknemers.

Om ingewikkelde discussies en regels te voorkomen werken de vakbonden ook aan een regeling waarbij inkomen als maatstaf dient om toch met 65 jaar met pensioen te kunnen gaan. Werknemers met een jaarsalaris van minder dan $€ 35.000$ (voorstel FNV) of $€ 25.000$ (VNO-NCW) zouden gewoon met 65 jaar met pensioen moeten kunnen gaan. Hier voelt de minister weer weinig voor, omdat in het geval van het FNV-voorstel de helft van de beroepsbevolking alsnog met 65 jaar met pensioen kan en dus de bezuinigingsdoelstelling (om ons sociale stelsel überhaupt betaalbaar te houden) niet wordt gerealiseerd.

In deze discussies wordt echter voorbijgegaan aan het feit dat bij de huidige pensioengerechtigde leeftijd van 65 de meeste medewerkers al op 62-jarige leeftijd stoppen met werken. Hoe komt het dat ouderen nu al niet doorwerken tot hun $65^{e}$ ? En in hoeverre kunnen we dan verwachten dat ze bij verhoging van de AOW-leeftijd wel langer zullen doorwerken? Een belangrijke reden voor het geringe aantal 63- en 64-jarigen dat nog aan het werk is, ligt in de inflexibele arbeidsmarkt voor ouderen. Zoals ook Coen Teu-

* Roel Schouteten is lid van de redactie van TvA. E-mail: r.schouteten@fm.ru.nl 
lings tijdens ons TvA/NAD-congres ${ }^{2}$ aangaf, is het door allerlei vooroordelen en de hoge salariskosten voor ouderen moeilijk om een nieuwe baan te vinden. Omdat werkloze 55-plussers maar $10 \%$ kans hebben om een baan te vinden, en 60-plussers slechts $3 \%$, is het ontzie-beleid in Nederland hardnekkig en houdt het zichzelf in stand.

Een andere reden voor de lage arbeidsparticipatie van ouderen is dat het financieel mogelijk of aantrekkelijk is om eerder te stoppen met werken. Aan die mogelijkheden is de laatste jaren echter al stevig paal en perk gesteld. Een derde reden is dan nog dat het werk voor ouderen niet is vol te houden. Werknemers vallen uit omdat ze ziek zijn geworden van hun werk. De redenen daartoe zijn divers; het kan gaan om fysieke klachten, maar ook om burnout. Volgens TNO-onderzoek zijn psychische aandoeningen de belangrijkste oorzaak voor ruim $40 \%$ van de mensen die jaarlijks geheel of gedeeltelijk arbeidsongeschikt raken.

De oudere krantenknipsels die ik in mijn stapel tegenkwam, bevatten analyses, waarschuwingen en aanknopingspunten die nauw verwant zijn aan de hiervoor geschetste discussies en problemen. In het begin van deze eeuw verschenen er berichten over de noodzaak na te denken over hoe het sociale stelsel betaalbaar te houden als de babyboomers op (korte) termijn met (vervroegd) pensioen zouden gaan. Er werd bijvoorbeeld ook gewezen op de noodzaak tot langer doorwerken en dat werkgevers moesten nadenken over hoe werknemers langer aan de slag te houden. Halverwege het eerste decennium werd er echter ook al geconstateerd dat bijna de helft van de werkgevers geen maatregelen treft om oudere werknemers langer aan het werk te houden. ${ }^{3}$ Tegelijkertijd verschijnen er berichten over werkdruk, ziekteverzuim en (on)tevredenheid op het werk, ${ }^{4}$ belangrijke indicatoren voor toekomstige arbeidsongeschiktheid.

Ook zijn er regelmatig berichten verschenen over wat werknemers belangrijk vinden in hun werk. ${ }^{5}$ Hoewel sommige berichten tegenstrijdige geluiden laten horen, omdat ze zich op andere, meer of minder wetenschappelijk zorgvuldige, onderzoeken baseren, wordt hieruit wel duidelijk dat er al tal van onderzoeken zijn verricht, die aanknopingspunten kunnen bieden om (oudere) medewerkers langer, gezond en gemotiveerd aan het werk te houden. In die zin heeft Minister Donner een punt als hij zegt dat werkgevers verantwoordelijk moeten zijn voor het op een zodanige manier organiseren van het werk dat werknemers er niet ziek van worden. Dit staat trouwens ook met zoveel woorden al in de Arbowet. Als werkgevers deze verantwoordelijkheid serieus nemen, en werknemers ook ten volle meewerken aan hun eigen duurzame inzetbaarheid, dan is de discussie over wat zware beroepen zijn overbodig. Er zou veel meer aandacht moeten zijn voor de vraag hoe de sociale partners (gezamenlijk) ervoor kunnen zorgen dat het aantal werkende ouderen groeit, zodat ons sociale stelsel betaalbaar blijft, ook voor de toekomstige generaties.

Bijdragen in TvA bieden vaak, op basis van gedegen wetenschappelijk onderzoek, aanknopingspunten voor het beantwoorden van de vraag welke maatregelen kunnen bijdragen aan het daadwerkelijk op een goede en gezonde manier bereiken van de pensioengerechtigde leeftijd. Dit nummer bevat daartoe weer enkele treffende voorbeelden. Joris Van Ruysseveldt maakt aannemelijk dat het voor werkgevers verstandig is om uitputtende werkomstandigheden te beperken en tevens ervoor te zorgen dat het werk zodanig wordt ingericht (via taakontwerp) dat er mogelijkheden zijn tot werkplekleren, hetgeen bijdraagt aan de duurzame inzetbaarheid van werknemers. Uit het onderzoek van Jos Sanders en zijn collega's blijkt dat een gezonde leefstijl bijdraagt aan de 
arbeidstevredenheid van medewerkers. En de bijdrage van Arie Gelderblom en zijn collega's bevat aanbevelingen om de (duurzame) inzetbaarheid van allochtone jongeren te vergroten.

\section{Noten}

1 Ten tijde van het schrijven van deze inleiding (20 januari 2010) vinden AOW-hoorzittingen plaats, waarin eens te meer duidelijk wordt dat de sociale partners daarover nog lang niet zijn uitgediscussieerd.

2 Ter ere van de 25e jaargang van TvA vond er op 14 oktober 2009 in het SER-gebouw een congres plaats met de titel 'Arbeid in crisis?'

3 'Hoe grijs kan het worden?', Intermediair, 31-8-2006; 'Doorwerken tot je 65 $5^{\text {ste }}$ is gezond: de tijd vliegt voorbij,' de Volkskrant, 25-8-2006.

4 'Werknemer is best wel tevreden,' de Volkskrant, 2-7-2003; 'Werknemers steeds meer onder druk,' ANP, 26-11-2003; 'Meer werkdruk, toch plezier,' Intermediair, 2-5-2004; 'Nederlandse werknemer minder gelukkig,' PenO Actueel, 7-7-2005; 'Stress en RSI kosten jaarlijks 6 miljard,' Nu.nl, 9-2-2006; 'Minder ziekteverzuim door slechte werksituatie,' Nu.nl, 13-6-2006; 'Vier op de tien werknemers niet blij op het werk,' Nu.nl, 13-9-2006; 'Plezieriger op de Nederlandse werkvloer,' Nu.nl, 15-3-2007; 'Zorgen om werkdruk in onderwijs,' de Volkskrant, 10-4-2007; 'Flexibel werken schaadt arbeidsvreugde,' Nu.nl, 24-4-2007; 'Personeel bezorgd om werkdruk,' de Volkskrant, 2-5-2007; 'Eén op vier werknemers heeft vaak stress,' Nu.nl, 22-2-2008; 'Ziekteverzuim zorg lijkt weer te stijgen,' Nu.nl, 27-3-2008.

5 'Nederlanders minder enthousiast over flexibele werktijden,' Nu.nl, 6-4-2005; 'Loon is goed, lol is beter,' Intermediair, 30-6-2005; 'Werknemer levert graag loon in voor minder stress,' Managers online.nl, 6-11-2006; 'Werknemer: geld is belangrijkste,' de Volkskrant, 24-10-2007; 'Salaris speelt kleine rol bij betrokkenheid,' Intermediair, 9-1-2008; 'Sfeer en geld belangrijker dan inhoud werk,' Persbericht Ad Rem Young Professionals, 2-4-2008; 'Werknemer: sociale werkomgeving belangrijkst,' PenO Actueel, 1-9-2008. 